\title{
Innovative Leadership Management in Early Children Education
}

\author{
Moh. Ali \\ Manajemen Pendidikan Islam Institut Agama Islam Negeri, Syekh Nurjati Cirebon, \\ Indonesia \\ DOI: 10.31004/obsesi.v6i4.2198
}

\begin{abstract}
The focus of this research is to find out how the pattern of innovative leadership management in early childhood education is. The purpose of this study was to describe innovative leadership management in early childhood education. The research was conducted using a qualitative approach with the type of literature study. The process of collecting data is done by means of a literature study. This method is a literature review from various sources and relevant references. This study came to the conclusion that innovative leaders are able to complete several ideas by implementing a systematic function from planning to evaluation. There must be teamwork through creativity and team innovation, and innovative and creative ways of working and understanding actual digital information. Of course, leaders need team assistance in carrying out their duties in providing quality learning services through innovation and learning activities.
\end{abstract}

Keywords: innovative leadership; management; early children education

\begin{abstract}
Abstrak
Fokus penelitian ini adalah untuk mengetahui bagaimana pola manajemen kepemimpinan inovatif di PAUD. Tujuan dari penelitian ini adalah untuk mendeskripsikan manajemen kepemimpinan yang inovatif pada pendidikan anak usia dini. Penelitian ini dilakukan dengan menggunakan pendekatan kualitatif dengan jenis studi kepustakaan. Proses pengumpulan data dilakukan dengan cara studi kepustakaan. Metode ini merupakan tinjauan pustaka dari berbagai sumber dan referensi yang relevan. Studi ini sampai pada kesimpulan bahwa pemimpin yang inovatif mampu menyelesaikan beberapa ide dengan menerapkan fungsi sistematis dari perencanaan hingga evaluasi. Harus ada kerja sama tim melalui kreativitas dan inovasi tim, serta cara kerja yang inovatif dan kreatif serta memahami informasi digital aktual. Tentunya pimpinan membutuhkan pendampingan tim dalam menjalankan tugasnya dalam memberikan layanan pembelajaran yang berkualitas melalui kegiatan inovasi dan pembelajaran.
\end{abstract}

Kata kunci: kepemimpinan inovatif; pengelolaan; pendidikan anak usia dini

Copyright (c) 2022 Moh. Ali

$\triangle$ Corresponding author:

Email Address : moh.ali@syekhnurjati.ac.id (Cirebon, Indonesia)

Received 29 November 2021, Accepted 17 January 2022, Published 13 February 2022 


\section{INTRODUCTION}

Leadership management is an important factor in the educational process because it determines success in the learning process. Especially in early childhood education, where teachers are tasked with fostering, guiding, and growing potential that can shape basic behaviours and abilities that are appropriate for their age and become provisions for taking the next level of education (Utiarahman, Pangayow, \& Arwildayanto, 2017). During the normalization of the current learning process, schools are required to be able to place students in a comfortable, safe, and interesting learning environment (Djafri, 2020). In this stage of education, an effective and innovative learning process is needed.

To realize an effective and innovative learning process, it must be started from the innovative leadership spirit of the principal (Asbari, Santoso, \& Purwanto, 2019). In fact, there are still many teachers who have not implemented innovative learning, which has implications for the occurrence of learning loss. Given that education greatly determines student competence, it is necessary for the principal's role in inspiring teachers to be able to realize innovative learning (Candra, Sabandi, Syahril, \& Zikri, 2020).

Innovative leadership in early childhood education is a pioneer in realizing an effective learning process. A mature concept is needed as well as structured and guided management from the principal because early childhood education is the first level of education for children (Sunarti, Uwie, \& Sumitra, 2018). Innovative thinking that exists in school principals also plays an important role in decision making and problem-solving, as well as conveying creative ideas in schools. In addition, it can also provide space for teachers to develop innovative, skilled, and effective learning processes. Principals are expected to dare to take risks to innovate in solving problems or making decisions for the sake of school progress (Kusniawan et al., 2019; Wiriyanto, 2020).

From the description above, it can be seen that innovative leadership management in the early childhood education learning process is very important. Innovative leadership management is expected to be able to provide a bright spot to improve the current state of education. The novelty in this research is the research objective which is to reveal innovative leadership management in prioritizing the uniqueness of the institution or school identity to achieve excellence. so the purpose of this study is to describe innovative leadership management in early childhood education in improving the quality of education.

\section{METHODOLOGY}

The research was conducted using a qualitative approach with the type of literature study. The process of collecting data is done by means of a literature study. This method is a literature review from various sources and relevant references. According to Sugiyono (2017) literature study is done by reading theoretical studies and other references related to the study being researched. Search literature using online using the application Publis or Perish by searching for the same topic, then sorting out the time of publication of the literature at least the last 10 years, the results obtained from several references are re-sorted to obtain results that are in accordance with the topic, title, and abstract to be researched and become a topic of discussion. The data collection process adopts Harijanto (2018) as shown in Figure 1.

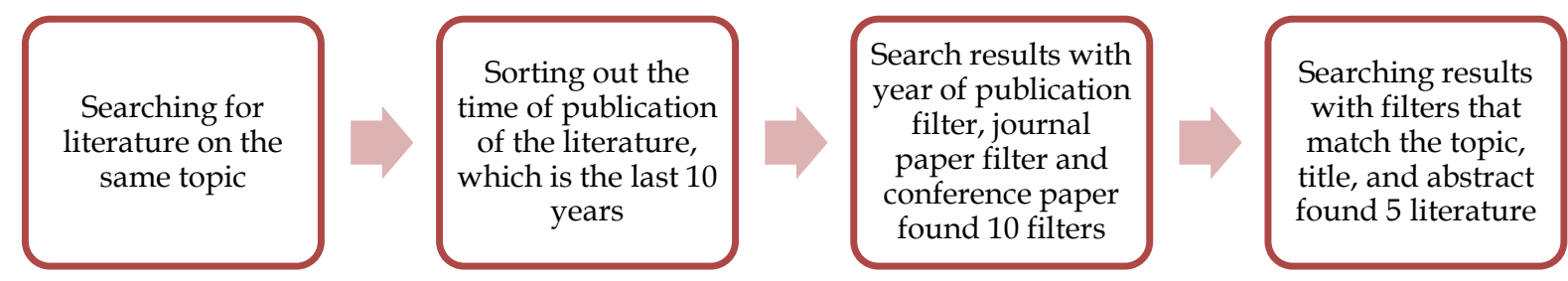

Figure 1. The Process of Obtaining Data. 


\section{RESULTS AND DISCUSSIONS}

Leadership management is a hot topic that has received the most attention from academics and practitioners. This is evidenced by the many articles, books, seminars, or research on the topic. The importance of leadership management is reflected in the existence of several theories or approaches to leadership, such as the trait and behavioural approach. We need to realize that there is no perfect and universal leadership management for all situations and environments. Leadership management aims to provide a change in an organization.

In this study, a literature study was conducted first by searching for literature relevant to the topic to be discussed. The search was carried out through an electronic source, namely Google Scholar. The search is only carried out on one source because that source is a source of articles and journals that are widely known and for Indonesian language journals that are suitable for the topic to be discussed, it is easy to access. Then the search was selected based on the year of publication, type of paper, and the suitability of the title and abstract with the topic, it was found that the number of papers to be analyzed was 5 pieces of literature. After obtaining the relevant literature, it is continued to conduct a deeper study. The list of articles that have been reviewed by the author is shown in Table 1 .

In the first literature, innovation in education is intended to solve problems in education by updating strategies and ideas that have been carried out. Innovation leadership management is carried out by implementing a combined curriculum from the ministry of education and culture, the ministry of religion, and its own institutions. So that in the learning process there is an integration between the formal curriculum and the institutional curriculum. In addition, innovation in human resources can be done by increasing the competence and professionalism of teachers in teaching. Furthermore, learning innovation is carried out by integrating pesantren and school learning referring to the combined curriculum between formal and Islamic boarding schools. This is in line with the results of Maiza \& Nurhafizah (2019) which states that the incorporation of the curriculum in schools can provide innovation in learning and also open views for teachers so that they can be updated on existing changes.

In the second literature, innovation leadership management is carried out to deal with the current global competition of educational organizations, where innovation management is a means to apply a new process of management to change for the better. This innovation involves more people than technology because it is able to provide criticism and suggestions. Considering that an educational institution is an institution that must innovate by involving other stakeholders.

There are several processes that must be passed in innovation management, namely (Dissatisfaction status quo) not being satisfied with something that remains, (Inspiration from other sources) requiring inspiration or input from other parties, (Invention) discovery of new ideas or strategies, (Internal) and external validation) validate the advantages and disadvantages of innovation to institutions, (diffusion) the success or failure of the ideas built depends on the communication that exists within the institution (Hutauruk, 2019).

In addition, the development of innovation management can be developed in educational institutions, including creating knowledge management, creating new business models, creating administrative innovations, designing curriculum, designing learning processes (Supriadi, 2017). With several existing processes, research on this second literacy provides a new view that innovative leadership management can excel educational organizations to face global competition.

In the third literature, it is explained that to improve the quality of education in each school it is necessary to have good leadership. Visionary, innovative leadership, skilled in managerial and integrity capable of improving the quality of education. There are several characteristics of effective and innovative leadership, including firm and fair in making decisions and assigning tasks, respecting the hard work of the staff, good problem-solving skills and having a vision for change, and having professional knowledge and competence 
(Anas \& Abdullah, 2021). In addition, this study states that to achieve innovative leadership, it must be based on 3 dimensions, namely based on values that refer to the vision and mission of the institution, the basis of work ethic which refers to self-awareness of the task at hand, and the basis of dedication. refers to the leader's ability to make changes.

Table 1. List of Reviewed Literature

\begin{tabular}{|c|c|c|}
\hline Researcher Name & Title & Recommendations \\
\hline Sofanudin (2016) & $\begin{array}{l}\text { Innovation } \\
\text { Management } \\
\text { quality-oriented } \\
\text { Education In } \\
\text { Wahid Hasyim } \\
\text { Yogyakarta MI }\end{array}$ & $\begin{array}{l}\text { Management is a quality-oriented education innovation } \\
\text { the process of managing new resources (ideas, practices, } \\
\text { objects, methods) in the field of education to achieve } \\
\text { educational goals or solve educational problems. New } \\
\text { ideas, practices, objects, and methods are meant to be } \\
\text { something that is already running, already exists, has } \\
\text { been practised in the daily management process within } \\
\text { the framework of improving the quality of education. At } \\
\text { MI Wahid Hasyim Yogyakarta, several educational } \\
\text { innovations were found, namely (1) Curriculum } \\
\text { Innovation, (2) Human Resource Innovation, and } \\
\text { (3)Quality Learning Innovation }\end{array}$ \\
\hline Nurjanah(2019) & $\begin{array}{l}\text { The Role of } \\
\text { Innovation } \\
\text { Management in } \\
\text { Improving } \\
\text { Educational } \\
\text { Organization } \\
\text { Performance }\end{array}$ & $\begin{array}{l}\text { Innovation management will create excellence an } \\
\text { educational organization so that the organization will } \\
\text { become an organization that is ready to face global } \\
\text { competition. To make the above breakthroughs, it is } \\
\text { necessary to have support to facilitate innovation, namely } \\
\text { Creativity, Knowledge, Competence, and Innovation } \\
\text { needs to be driven by community needs rather than } \\
\text { policies and processes. }\end{array}$ \\
\hline $\begin{array}{l}\text { Nurdin \& } \quad \text { Aedi } \\
\text { (2019) }\end{array}$ & $\begin{array}{l}\text { Revitalizing } \\
\text { Islamic Education } \\
\text { Institutional } \\
\text { Management at } \\
\text { the Madrasah } \\
\text { Ibtidaiyah Level in } \\
\text { Bandung City } \\
\text { Through } \\
\text { InnovativeInnovat } \\
\text { ive }\end{array}$ & $\begin{array}{l}\text { Leadershipleadership is one of the keys to making } \\
\text { educational changes, namely those related to institutional } \\
\text { system management. Innovations that are more } \\
\text { prominent in the educational environment are more } \\
\text { focused on the administrative side or on the material and } \\
\text { teaching side, not yet on the institutional managerial } \\
\text { aspect. Management of educational institutions has a } \\
\text { very important factor to be improved and improved so } \\
\text { that the weaknesses that exist in the institution can be } \\
\text { overcome properly. }\end{array}$ \\
\hline Suyitno (2021) & $\begin{array}{l}\text { Innovative } \\
\text { Leadership in } \\
\text { Education } \\
\text { Delivery in the } \\
\text { Covid-19 } \\
\text { Pandemic Period } \\
\text { Innovative }\end{array}$ & $\begin{array}{l}\text { management of school principals by preparing various } \\
\text { plans to support the learning process for students can be } \\
\text { carried out with innovations made by Principals, among } \\
\text { others, to answer and unravel three challenges, namely } \\
\text { the curriculum what will be used, develop learning } \\
\text { strategies, and use information technology. }\end{array}$ \\
\hline Syam (2020) & $\begin{array}{l}\text { Innovative } \\
\text { Educational } \\
\text { Leadership }\end{array}$ & $\begin{array}{l}\text { Innovation and expertise and quality. The skills that must } \\
\text { be possessed by innovative leadership are managerial } \\
\text { and leadership skills. Managerial skills are needed so that } \\
\text { leaders are able to handle the complexity of educational } \\
\text { institutions, educational leadership skills are needed in } \\
\text { order to obtain innovative leaders in leading educational } \\
\text { institutions to match the expectations of educational } \\
\text { autonomy. }\end{array}$ \\
\hline
\end{tabular}


By following this basis, it can be seen from the results of the research that there have been changes in institutional education services, the number and qualifications of teachers, and the number of students who are the result of innovations in improving the quality of educational inputs, processes, and outputs.

In the fourth literature, the innovation of a leader is the main demand in building reforms in schools during this pandemic, including simplifying the curriculum by mapping learning area competencies and evaluating essential materials in the curriculum. In addition, it can reduce the material to make it easier for students to understand independently and adjust learning strategies. And provide support for teacher creativity in utilizing learning media. This period of normalization or new normal education requires leadership that is able to face crises in all circumstances, such as innovative leadership. Innovative leadership in education can be realized in managing and making decisions for the evaluation phase, starting at the planning, management, indicator development stages into a core program of innovative leadership in learning by paying attention to the adaptation of responsive and applicable information technology for implementation (Syafaruddin, Asrul, Mesiono, 2019).

This is in line with the research of Nugroho et al., (2021) which says that innovative leadership is suitable in dealing with crises because of the advantages it has, such as 1) being able to anticipate needs, modes of interest and choice in the future, 2) being active in building knowledge and joint participation in taking action for future needs, 3) adapting in updating and adjusting learning according to the response needed 4) being fair, impartial in making decisions and open to challenges and feedback received. The breakthroughs made in this study to improve the quality of education are by mapping competencies by bringing similar learning areas closer together and evaluating them, selecting learning strategies that are innovative and creative in using media effectively, and utilizing information technology.

In the fifth literature, it is explained that quality improvement in education fails if the strategy used overrides inspiration, creativity and school activities. Meanwhile, innovation is needed by schools for students, the school environment, and the advancement of science and technology. In the current autonomy education, a leader must have more authority to innovate in education. So innovative leadership is needed that is in synergy with resources in education so that it can accelerate the rate of improving the quality of education (Pasaribu, 2017).

Some of the skills that innovative leaders must possess include 1) building community innovations in educational institutions, 2) choosing directions and dealing with problems properly and appropriately, 3) being a catalyst to change attitudes and behaviour of the educational institution community for the better (Wardoyo, 2017). From some of the explanations above, it can be seen that the importance of innovative leaders to change the quality of education and the performance of educational institutions.

This study focuses on the skills that a leader must possess in improving the quality of education, namely managerial skills and leadership skills. Managerial skills include expertise in honest strategic and operational planning, managing coordinated education, and evaluating in a reliable and valid manner. Meanwhile, leadership skills include being motivated in the educational community, being able to determine direction and handle change appropriately, as well as being a catalyst in the educational institution community.

\section{CONCLUSION}

Innovative leaders are able to complete several ideas by implementing a systematic function from planning to evaluation. There must be teamwork through creativity and team innovation, and innovative and creative ways of working and understanding actual digital information. Of course, leaders need team assistance in carrying out their duties in providing quality learning services through innovation and learning activities. 


\section{ACKNOWLEDGMENT}

Terima kasih penulis sampaikan kepada Dekan fakultas ilmu tarbiyah dan keguruan (FITK) IAIN Syekh Nurjati Cirebon dan semua pihak yang telah bersedia berpartisipasi dalam penelitian sehingga penelitian ini dapat terselesaikan.

\section{REFERENCES}

Anas, A., \& Abdullah, M. T. (2021). Kepemimpinan Inovatif Dalam Pelaksanaan Program Swasembada Pangan Nasional. Publisia: Jurnal Ilmu Administrasi Publik, 6(2), 90-99. https:// doi.org/10.26905/pjiap.v6i2.6091

Asbari, M., Santoso, P. B., \& Purwanto, A. (2019). Pengaruh Kepemimpinan dan Budaya Organisasi Terhadap Perilaku Kerja Inovatif pada Industri 4.0. Jim UPB, 8(1), 7-15. https:// doi.org/ttps://doi.org/10.33884/jimupb.v8i1.1562

Candra, A., Sabandi, A., Syahril, S., \& Zikri, A. (2020). Kontribusi Kepemimpinan Kepala Sekolah dan Insentif terhadap Motivasi Berprestasi Guru. Jurnal Basicedu, 4(3), 690695. https:// doi.org/10.31004/basicedu.v4i3.379

Djafri, N. (2020). Pengaruh Gaya Kepemimpinan dan Budaya Kerja Kepala Sekolah di Pendidikan Anak Usia Dini. Jurnal Obsesi : Jurnal Pendidikan Anak Usia Dini, 4(2), 940. https://doi.org/10.31004/obsesi.v4i2.494

Harijanto, A. (2018). Seminar Nasional Pendidikan Fisika 2018 Seminar Nasional Pendidikan Fisika 2018. 3, 162-166.

Hutauruk, T. R. (2019). Manajemen Inovasi Sebagai Solusi Kebijakan Terhadap Persoalan Sampah Plastik Di Kota Samarinda (Management As a Solution for Policy To Solve the Problem of Plastic Waste in Samarinda City ). Jurnal Riset Inossa, 1(1), 1-12. https://doi.org/10.54902/jri.v1i1.3

Kusniawan, W., Zaini, H. A., Saputra, R., \& Hillay, A. (2019). Kepemimpinan dalam Pendidikan Islam. AL-FAHIM: Jurnal Manajemen Pendidikan Islam, 1(2), 1-17. https:// doi.org/10.54396/alfahim.v1i2.54

Maiza, Z., \& Nurhafizah, N. (2019). Pengembangan Keprofesian Berkelanjutan dalam Meningkatkan Profesionalisme Guru Pendidikan Anak Usia Dini. Jurnal Obsesi: Jurnal Pendidikan Anak Usia Dini, 3(2), 356. https:/ / doi.org/10.31004/obsesi.v3i2.196

Nugroho, I., Paramita, N., Mengistie, B. T., \& Krupskyi, O. P. (2021). Higher education leadership and uncertainty during the COVID-19 pandemic. Journal of Socioeconomics and Development, 4(1), 1. https:// doi.org/10.31328/jsed.v4i1.2274

Pasaribu, A. (2017). MBS perspektif islam. EduTech Vol. 3 No. 1 Maret 2017, 3(1), 12-34.

Sugiyono. (2017). Metode Penelitian Kuantitatif, Kualitatif dan R\&D. bandung: alfabeta.

Sunarti, C., Uwie, W., \& Sumitra, A. (2018). Pembentukan Karakter Mandiri Pada Anak Usia Dini Melalui Metode Montessori Di Tk Almarhamah Cimahi. CERIA (Cerdas Energik Responsif Inovatif Adaptif), 1(2), 47. https:// doi.org/10.22460/ceria.v1i2.p47-57

Supriadi, D. (2017). Implementasi Manajemen Inovasi dan Kreatifitas Guru dalam Meningkatkan Mutu Pembelajaran. Indonesian Journal of Education Management and Administration Review, 1(2), 125-132.

Syafaruddin, Asrul, Mesiono, P. (2019). Inovasi Pendidikan. In Media Komunikasi SMP dan MTs.

Utiarahman, P., Pangayow, W., \& Arwildayanto, A. (2017). Manajemen Program Akreditasi Pada Sekolah Menengah Pertama Negeri Di Kabupaten Boalemo. Paper Knowledge . Toward a Media History of Documents, 02, 124-129.

Wardoyo, D. (2017). Peningkatan Pemahaman Konsep Tentang Pemerintahan Pusat Pada Pelajaran Pkn Melalui Metode Point Counter Point (Pcp) Pada Siswa Kelas Iv Sd Muhammadiyah Plosorejo. Skrip, 1-12.

Wiriyanto, B. (2020). Kepemimpinan Inovatif Kepala Daerah untuk Sektor Publik di Kabupaten Banyuwangi (Studi Kasus Bupati Abdullah Azwar Anas). In Repository.Unej.Ac.Id. 